\title{
Can Burn Injury Cause Thrombotic Thrombocytopenic Purpura?
}

\author{
Mehmet Akif Öztürk, ㄷNisa Babacanlar, 두 Cafer Akkoz, ㄷ Ali Özdemir
}

Department of Internal Medicine, Fatih Sultan Mehmet Training and Research Hospital, İstanbul, Turkey

$\begin{array}{r}\text { Submitted: 05.10.2018 } \\ \text { Accepted: 05.03.2019 } \\ \text { Correspondence: } \\ \text { Mehmet Akif Öztürk, } \\ \text { Fatih Sultan Mehmet Eğitim ve } \\ \text { Araştırma Hastanesi, Iç Hastalıkları } \\ \text { Kliniği, İstanbul, Turkey } \\ \text { E-mail: akifozturk@hotmail.com } \\ \hline\end{array}$

Keywords: Anemia; burn; thrombotic thrombocytopenic purpura.

\begin{abstract}
Thrombotic thrombocytopenic purpura (TTP) is characterized by the pentad of microangiopathic hemolytic anemia, uremia, thrombocytopenia, neurological symptoms, and fever. It can be a fatal emergency if early diagnosis and appropriate evaluation are not performed. TTP is associated with an acquired or congenital deficiency of the von Willebrand factorcleaving metalloprotease, ADAMTSI3. It can be triggered by many diseases or drugs. Plasma exchange, which is an urgent treatment modality, can be effective in cases of TTP. Presently described is the case of a 35-year-old man with a diagnosis of TTP that developed after a burn injury. The underlying mechanism of TTP development after a burn is still unknown. Clinicians should pay attention to neurological symptoms and thrombocytopenia after burn accidents and must be alert to this life-threatening situation.
\end{abstract}

\section{INTRODUCTION}

Thrombotic thrombocytopenic purpura (TTP) is characterised by the pentad of microangiopathic haemolytic anaemia, uraemia, thrombocytopenia, neurological symptoms and fever. It may prove to be fatal if early diagnosis and appropriate evaluation is not done. Here we report the case of a patient in whom TTP developed after a burn injury.

\section{CASE REPORT}

A 35-year-old man was admitted to emergency department with the complaints of headache, fever, dysarthria and dysaesthesia. Tonic convulsions and agitation were observed following plegia of upper extremities in the emergency department. His past medical history comprised a second-degree burn on his left upper extremity and face ( $13 \%$ of the total body) I5 days ago. There was no history of drug use. Physical examination showed a body temperature of $38^{\circ} \mathrm{C}$, heart rate of $88 \mathrm{bpm}$, blood pressure of $140 / 90 \mathrm{mmHg}$, oxygen saturation of $99 \%$ and Glasgow Coma Scale (GCS) score of 8 . His com- plete blood count showed that he had thrombocytopenia (platelet count 19,000 $\mu / \mathrm{L}$ ), anaemia (haemoglobin concentration $7.7 \mathrm{~g} / \mathrm{dL}$, haematocrit 23.2\%) and leucocytosis (white blood cell count $15,700 \mu / L$ ). Furthermore, his biochemical tests showed increased lactate dehydrogenase (LDH, $1323 \mathrm{U} / \mathrm{L}$ ), blood urea nitrogen (BUN, 20 $\mathrm{mg} / \mathrm{dL})$, creatinine $(1.49 \mathrm{mg} / \mathrm{dL})$ and total bilirubin $(2.31$ $\mathrm{mg} / \mathrm{dL}$ ) levels. Coagulations tests, D-dimer and fibrinogen levels were normal. Fragmented erythrocytes were observed in his blood smear (Fig. I). Blood sample was collected for ADAMTSI 3 measurement. On the basis of the above clinical and laboratory findings, the patient was diagnosed with TTP and was transferred to intensive care unit. Treatment with a corticosteroid $(1 \mathrm{mg} / \mathrm{kg})$ and plasmapheresis were simultaneously started. The clinical condition of the patient improved, and his GCS score increased to 15 after 3 cycles of plasmapheresis. Furthermore, his laboratory test values improved with a platelet count of $35 \mathrm{I}, 000 \mu / \mathrm{L}$; haemoglobin concentration of 10.3 $\mathrm{g} / \mathrm{dL}$; and BUN, creatinine and LDH levels of $23 \mathrm{mg} / \mathrm{dL}$, $0.9 \mathrm{mg} / \mathrm{dL}$ and $329 \mathrm{U} / \mathrm{L}$, respectively. ADAMTSI 3 activity was detected to be $<10 \%$ in the blood sample collected before plasmapheresis. 


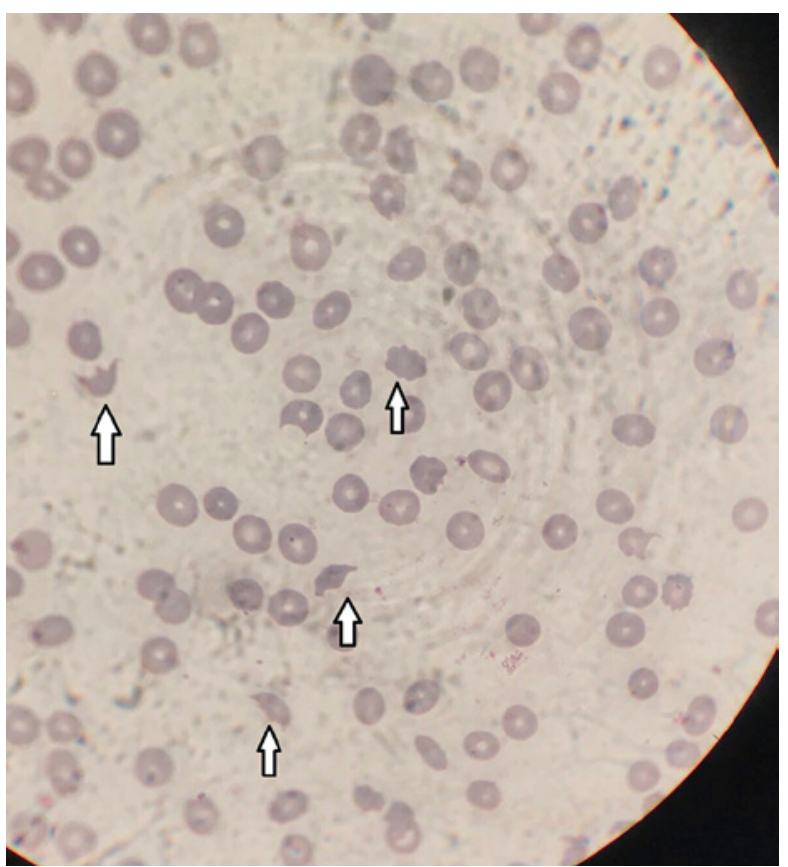

Figure 1. Arrow: fragmented erythrocytes in the patients blood smear.

\section{DISCUSSION}

TTP was first described by Moschcowitz in 1924. TTP is associated with acquired or congenital deficiency of the von Willebrand factor-cleaving metalloprotease, ADAMTSI 3. It is characterised by the pentad of microangiopathic haemolytic anaemia, fever, neurological symptoms, thrombocytopenia and acute renal failure. The incidence of acquired TTP is 3 cases per million population. ${ }^{[l]}$

Pathophysiologically, undetectable levels of enzyme activity or an autoantibody to ADAMTSI 3 leads to the activation of coagulation cascade that subsequently results in platelet aggregation, microembolus of the small vessels and erythrocyte fragmentation. These pathophysiological features of the disease cause microangiopathic haemolytic anaemia and thrombocytopenia. The presence of ADAMS-13 inhibitor is important for the acquired or hereditary discrimination. Diseases such as disseminated intravascular coagulation, Evans syndrome and systemic lupus erythematosus may be considered in the differential diagnosis of microangiopathic haemolytic anaemia and thrombocytopenia. ${ }^{[2,3]}$ Clinically, major or minor neurological symptoms, bleeding or purpura, weakness and fever may occur. Our patient exhibited all the elements of the TTP pentad.

Plasma exchange, which is an urgent treatment modality, is effective in TTP. ${ }^{[4-6]}$ Simultaneous glucocorticoid administration in addition to plasma exchange is a preferred treatment method. ${ }^{[7,8]}$ We used both plasma exchange and glucocorticoids in our patient and achieved a satisfactory result with the treatment.

TTP can be triggered by many diseases or drugs. We believe that it was triggered by burns in the present case. The appearance of the condition 15 days after the burn event is thought to be associated with a slow immune mechanism. To the best of our knowledge, burn-induced TTP has not yet been reported. Thus, this case is different from other reported cases of TTP. Previously, the case of a I-year-old child who developed haemolytic uremic syndrome after a burn injury has been reported. ${ }^{[9]}$ The underlying mechanism of TTP development after burn is unknown.

In conclusion, clinicians should pay attention to neurological symptoms and thrombocytopenia after burn accidents and must be aware about this life-threatening situation.

Peer-review

Internally peer-reviewed.

Authorship Contributions

Concept: M.A.Ö., A.Ö., N.B.; Design: A.Ö., M.A.Ö.; Data collection \&/or processing: N.B, C.A.; Analysis and/or interpretation: M.A.Ö, C.A; Literature search: M.A.Ö; Writing: M.A.Ö; Critical review: M.A.Ö., A.Ö.

Conflict of Interest

None declared.

\section{REFERENCES}

1. Reese JA, Muthurajah DS, Kremer Hovinga JA, Vesely SK, Terrell DR, George JN. Children and adults with thrombotic thrombocytopenic purpura associated with severe, acquired Adamts13 deficiency: comparison of incidence, demographic and clinical features. Pediatr Blood Cancer 2013;60:1676-82. [CrossRef]

2. Page EE, Kremer Hovinga JA, Terrell DR, Vesely SK, George JN. Thrombotic thrombocytopenic purpura: diagnostic criteria, clinical features, and long-term outcomes from 1995 through 2015. Blood Adv 2017;1:590-600. [CrossRef]

3. George JN. Measuring ADAMTS13 activity in patients with suspected thrombotic thrombocytopenic purpura: when, how, and why? Transfusion 2015;55:11-3. [CrossRef]

4. Vesely SK, George JN, Lämmle B, Studt JD, Alberio L, El-Harake MA, et al. ADAMTS13 activity in thrombotic thrombocytopenic purpura-hemolytic uremic syndrome: relation to presenting features and clinical outcomes in a prospective cohort of 142 patients. Blood 2003;102:60-8. [CrossRef]

5. Pene F, Vigneau C, Auburtin M, Moreau D, Zahar JR, Coste J, et al. Outcome of severe adult thrombotic microangiopathies in the intensive care unit. Intensive Care Med 2005;31:71-8. [CrossRef]

6. Kremer Hovinga JA, Vesely SK, Terrell DR, Lämmle B, George JN. Survival and relapse in patients with thrombotic thrombocytopenic purpura. Blood 2010;115:1500-11. [CrossRef]

7. Allford SL, Hunt BJ, Rose P, Machin SJ; Haemostasis and Thrombosis Task Force, British Committee for Standards in Haematology. Guidelines on the diagnosis and management of the thrombotic microangiopathic haemolytic anaemias. Br J Haematol 2003;120:55673. [CrossRef]

8. Bell WR, Braine HG, Ness PM, Kickler TS. Improved survival in thrombotic thrombocytopenic purpura-hemolytic uremic syndrome. Clinical experience in 108 patients. N Engl J Med 1991;325:398-403.

9. Emil S, Rockstad R, Vannix D. Hemolytic uremic syndrome in a child with burn injuries. J Burn Care Rehabil 1998;19:135-7. [CrossRef] 


\section{Yanık Hasarı Trombotik Trombositopenik Purpuraya Yol Açar mı?}

Trombotik trombositopenik purpura (TTP), mikroanjiyopatik hemolitik anemi, üremi, trombositopeni, nörolojik semptomlar ve ateşin pentadı ile kendini gösteren bir hastalıktır. TTP erken tanı ve uygun değerlendirme yapılmadığında ölümcül olabilen acil bir durumdur. TTP ilk olarak 1924'te Moschcowitz tarafından tanımlanmıştır. TTP, von Willebrand faktörü-parçalayan metaloproteaz, ADAMTSI 3'ün edinilmiş veya doğuştan eksikliği ile ilişkilidir. Acil bir tedavi modalitesi olan plazma değişimi, TTP'de etkilidir. Birçok hastalık veya ilaç tarafından bu hastalık tetiklenebilir. Burada yanık sonrası gelişen TTP tanısı ile takip edilen 35 yaşında bir erkek hastayı sunuyoruz. Bu olguda, TTP'nin yanık ile tetiklendiğini düşünüyoruz. Yanık sonrası TTP gelişiminin altında yatan mekanizma bilinmemektedir. Klinisyenler, yanık kazalarından sonra nörolojik semptomlara ve trombositopenilere dikkat etmeli ve bu hayati tehlike arz eden durumlarda dikkatli olmalıdırlar.

Anahtar Sözcükler: Anemi; trombotik trombositopenik purpura; yanık. 